\title{
REPRESENTASI DAN STEREOTYPE KELOMPOK HIJABERS SEBAGAI BAGIAN DARI POP CULTURE
}

\author{
Ghina Novarisa \\ Program Pascasarjana Departemen Ilmu Komunikasi, Universitas Indonesia; \\ ghinanovarisa90@gmail.com
}

\begin{abstract}
ABSTRAK
Penelitian ini bertujuan mengungkan representasi dan stereotype dari komunitas hijab yang menamakan diri mereka "hijabers community" melalui gaya hidup dan nilai-nilai realitas yang ditampilkan kelompok tersebut. Hijabers community memproklamirkan dirinya sebagai kelompok hijab pertama di Indonesia. Adanya kelompok yang melabelkan diri mereka dengan mencirikan karakteristik tertentu tentunya bertujuan membedakan diri mereka dengan kelompok lain dan memunculkan status sosial mereka yang tercerminkan gaya hidup mereka.Gaya hidup biasanya adalah milik kaum yang memiliki kemampuan ekonomi menengah keatas. Oleh karena itu gaya hidup mereka menjadi prestise bagi mereka dan menciptakan kelas. Fenomena ini menarik perhatian untuk dilihat bagaimana sebenarnya representasi dan stereotype yang melekat pada gaya hidup kelompok hijaber. Metode penelitian yang digunakan adalah metode analisis wacana untuk memperlihatkan motivasi yang tersembunyi di belakang sebuah teks. Subjek penelitiannya adalah teks yang diproduksi dari kelompok "hijabers community" yaitu iklan cetak dari beberapa kegiatan yang dilakukan dan diadakan oleh kelompok "hijabers community". Hasilnya adalah representasi dan stereotype gaya hidup yang melekat pada kelompok hijabers "hijabers community' tersebut adalah pola gaya hidup kelompok kelas menengah keatas yang lebih konsumtif, mengajarkan kita untuk konsumtif, dimana pola tersebut digiring menjadi bagian pop culture.
\end{abstract}

Keywords: representasi, stereotype, hijabers community, pop culture

\begin{abstract}
The aim of this research is to express the representation and stereotypes of the hijab community who call themselves "hijabers community" through the lifestyle and reality values displayed by the group. Hijabers community proclaims itself as the first hijab group in Indonesia. the existence of this group characterizes certain characteristics of course aiming to differentiate themselves from other groups and bring up their social status that is reflected by their lifestyle. Lifestyle is usually the property of people who have middle and upper economic abilities. Therefore their lifestyle becomes prestige for them and creates class. This phenomenon attracts attention to be seen how the actual representation and stereotype inherent in the lifestyle of the hijaber group. The research method used is the discourse analysis method to show the hidden motivation behind a text. The subject of his research was the text produced from the "hijabers community" group, namely print advertisements of several activities carried out and organized by the "hijabers community" group. The result is a lifestyle representation and stereotype inherent in the hijabers "hijabers community" group is a lifestyle pattern of the middle class and above that is more consumptive, teaching us to be consumptive, where the pattern is herded into a part of pop culture.
\end{abstract}

Keywords: representation, stereotypes, hijabers community, pop culture 


\section{PENDAHULUAN}

Representasi secara umum merupakan sebuah cara dimana memaknai apa yang diberikan pada benda yang digambarkan. Segala sesuatu didunia ini harus direpresentasikan, baik itu direpresentasikan didalam kepala memaknai sesuatu disekitar kita ataupun merepresentasikan kehidupan sosial disekitar kita. Pada dasarnya, representasi merupakan kunci komunikasi. Representasi merupakan bagaiamana kita menyampaikan sesuatu yang bermakna kepada orang lain dengan bantuan bahasa. Representasi berarti menggunakan bahasa untuk mengatakan sesuatu yang bermakna, atau untuk mewakili, dunia yang penuh arti, untuk orang lain.

Representasi merupakan kunci penting dalam berkomunikasi, maupun dalam menyebarluaskan budaya. Konsep representasi menempati tempat yang penting dalam studi budaya. Representasi menghubungkan makna dan bahasa dengan budaya. Secara sederhana, hubungan representasi dan budaya adalah, budaya merupakan segala sesuatu tentang "berbagi makna", dan bahasa merupakan medium yang paling memungkinkan untuk memproduksi dan bertukar makna. Makna hanya bisa dibagi dengan akses kita terhadap bahasa. Representasi bagian penting dari proses dimana makna diproduksi dan dipertukarkan antara anggota suatu budaya. Hal ini melibatkan penggunaan bahasa, tanda dan gambar yang berdiri untuk mewakili sesuatu (Hall,1997;15).

Konsep umum"representasi" adalah sebuah cara dimana memaknai apa yang diberikan pada benda yang digambarkan. Namun demikian, sejalan dengan perkembangannya, Stuart Hall berargumentasi bahwa representasi harus dipahami dari peran aktif dan kreatif orang memaknai dunia.

"so the representation is the way in which meaning is somehow given to the things which are depicted through the images or whatever it is, on screens or the words on a page which stand for what we're talking about"

Hall menunjukkan bahwa sebuah imajinasi akan mempunyai makna yang berbeda dan tidak ada garansi bahwa imajinasi akan berfungsi atau bekerja sebagaimana mereka dikreasi atau dicipta. Hall menyebutkan "Representasi sebagai konstitutif". Representasi tidak hadir sampai setelah selesai direpresentasikan, representasi tidak terjadi setelah sebuah kejadian. Representasi adalah konstitutif dari sebuah kejadian. Representasi adalah bagian dari objek itu sendiri (Hall,1997).

Konsep representasi tidak sederhana lagi, representasi juga bisa direpresentasikan dalam cakupan yang lebih luas dan dalam lagi. Berbicara mengenai representasi tidak hanya makna yang setelah dimaknai selesai begitu saja. Representasi lebih luas dan dalam lagi bisa melibatkan elemen-elemen lain seperti adanya kekuasaan, komoditas, identitas, regulasi yang terlibat dalam pembentukannya. Menggunakan representasi, kita bisa membongkar pemaknaan suatu tanda yang diproduksi dan dikonsumsi oleh masyarakat.

Konsep representasi terus berkembang seiring perkembangan teknologi dan budaya. Pada saat sekarang ini konsep representasi tidak hanya berada pada tataran interpretatif namun juga pada tataran kritis. Pada saat sekarang ini, konsep ini sering digunakan pada penelitian yang berkaitan dengan media, baik media film, TV, musik, video, buku, majalah dan media baru (cyber media). Selain itu, konsep representasi juga digunakan dalam kajian budaya populer (populer culture). 
Budaya populer yang merupakan budaya rakyat, yang dikonsumsi oleh masyarakat banyak, direpresentasikan dengan banyak sudut padang tentunya. Budaya populer biasanya digunakan untuk mendapatkan informasi sebanyak-banyaknya, salah satunya informasi tentang daerah ataupun kebudayaan dari daerah lain yang belum pernah dikunjung yang pastinya memiliki kebudayaan yang berbeda. Faktanya, budaya sendiri adalah sebuah sistem representasi. Kebudayaan merupakan konsep yang sangat luas, kebudayaan menyangkut 'pengalaman berbagi'. Seseorang dikatakan berasal dari kebudayaan yang sama jika manusia-manusia yang ada disitu membagi pengalaman yang sama, membagi kode-kode kebudayaan yang sama, berbicara dalam 'bahasa' yang sama, dan saling berbagi konsep-konsep yang sama. Melalui budaya populer, kita belajar mengenai kebudayaan lain, merepresentasikannya dan kemudian representasi kita tidak jarang stereotype yang tertanam dalam pikiran kita. Representasi dan stereotype yang kita miliki menjadi modal dasar dalam berkomunikasi dengan orang lain yang memiliki budaya berbeda. Hal inilah yang menjadi dasar sederhana mengapa representasi dan stereotype penting dalam komunikasi anatar budaya. Selanjutnya, dengan menguasai komunikasi antar budaya tersebut, kita juga bisa menyebar luaskan budaya kita kepada orang lain. Seperti fenomena hijabers yang terjadi sekarang ini di Indonesia.

Pada awalnya esensi kerudung/hijab/jilbab adalah untuk menunjukkan identitas dan relijiusitas kelompok perempuan muslim. Kerudung/Hijab/Jilbab awalnya adalah sebuah benda yang kemunculanya akibat dari dorongan syaraiat, artinya munculnya ide budaya kerudung/Hijab/Jilbab berasal dari hukum Allah (Al Qur'an surat An - Nur (24): 31). Sehingga manusia tinggal memahami kemudian mewujudkanya. Awalnya Kerudung/Hijab/Jilbab masih sebatas sebagai fungsi teknis, artinya baru sebatas sebagai sebuah benda yang memiliki fungsi untuk menutupi bagian tubuh yang dilarang untuk dilihat oleh orang lain, untuk menghindari maksiat bagi yang melihat ( $\mathrm{Al} \sim$ Qur' an surat $\mathrm{Al}$ - Ahzab (33): 59).

Abad ke 7 adalah abad dimana awal perintah berkerudung/berhijab, dalam konteks abad ke 7 di semenanjung Arabia, kondisi sosial masyarakat jauh dari pengaruh peradaban dua imperium besar yaitu Romawi dan Persia(sejarah Muhammad, M Husein Haekal). Hal ini sebagai dampak dari geomorfologi Arab yang terpencil dan terkukung dari pegunungan dan padang pasir, hal ini berdampak pada pengaruh budaya yang cukup kecil terjadi, sehingga apa yang dikembangkan oleh masyarakat masih sesuai dengan doktrin yang ada di lingkungan masyarakat Arab. Kerudung/Hijab/Jilbab dengan cadar, burqa, niqop, dan masker, kemudian berkembang pula di Nusantara atau Melayu abad 19 Kerudung/Hijab/Jilbab selendang yang tidak menutupi penuh kepala, dan hanya di selampirkan. di kawasan timur juga berkembang Kerudung/Hijab/Jilbab dengan motif hiasan tertentu sesuai dengan konteks lingkunganya, tidak sebatas polos tanpa motif, dan lain sebagainya. Hingga sekarang perkembangan kerudung/jilbab /hijab memasuki fase hijab modern (www.kerudung.com).

Tak dapat dipungkiri, hijab modern merupakan produk pop culture yang disukai massa. Namun belakangan perkembangan jilbab terbawa arus globalisasi menjadi bagian dari budaya populer. Budaya ini merupakan budaya yang sering kali ditemukan dalam kehidupan sehari-hari orang banyak. Adanya diskriminasi terhadap perempuan berjilbab tidak lagi berlaku dengan ngetrennya hijab style baru yang biasa dikenal hijab modern. Gaya dan model jilbab yang trendy mengacu pada masa kekinian semakin diminati para 
perempuan Indonesia. Perempuan, selalu menjadi sorotan dalam dunia fashion, terutama bagi muslimah.

Menurut Raleigh (2004) jilbab tidak hanya sebagai simbol yang mencerminkan identitas agama, namun juga mencerminkan identitas kolektif. Jilbab menjadi trendi dan memakai jilbab mulai mencapai prestise tertentu, ini dikarenakan busana muslimah atau jilbab mampu mengkomunikasikan hasrat menjadi orang modern yang saleh dan sekaligus menjadi muslim yang modern. Salah satu kelompok yang mencermikan identitas kolektifnya adalah kelompok hijabers atau dikenal dengan hijabers community.

Hijabers community memproklamirkan dirinya sebagai kelompok hijab pertama di Indonesia. Perkembangannya menjadikan kelompok ini sebagai trendsetter jilbab dan busana muslim bagi muslimah di Indonesia. Adanya kelompok yang melabelkan diri mereka dengan mencirikan karakteristik tertentu tentunya bertujuan membedakan diri mereka dengan kelompok lain dan memunculkan status sosial mereka yang tercerminkan gaya hidup mereka. Gaya hidup biasanya adalah milik kaum yang memiliki kemampuan ekonomi menengah keatas. Oleh karena itu gaya hidup mereka menjadi prestise bagi mereka dan menciptakan kelas. Jilbab tidak lagi sekedar pakaian penutup kepala tetapi menjadi tempat memperlihatkan status dan prestise. Untuk mencapai pengakuan sosial yang tinggi, tidak jarang perempuan menganut budaya konsumerisme. Menggunakan jilbab rancangan desainer ternama dengan harga yang yang fantastis. Namun demikian, selalu ada tandingannya, bajakannya beredar dimanamana untuk kelas menengah kebawah dengan harga terjangkau tapi memiliki tujuan yang sama agar dikatakan mirip dengan kelompok tertentu. Fenomena ini menarik perhatian untuk menjawab pertanyaan penelitian, "Bagaimana sebenarnya representasi dan stereotype yang melekat pada gaya hidup kelompok hijaber?”

Setelah mengetahui representasi dan stereotype dari gaya hidup kelompok tersebut, tentunya yang sangat penting adalah apa kaitannya dengan komunikasi antar budaya. Melalui penelitian tersebut, perempuan khususnya yang juga behijab bisa mengetahui dan mendapatkan informasi gambaran umum gaya hidup mengenai kelompok tersebut. Hal tersebut bisa dijadikan referensi untuk berkomunikasi dengan orang-orang yang tergabung dalam kelompok tersebut ataupun menggunakan pola komunikasi dan budaya mereka dalam mengembangkan budaya populer lainnya.

\section{METODOLOGI PENELITIAN}

Penelitian ini bertujuan mengungkan representasi dan stereotype dari komunitas hijab yang menamakan diri mereka "hijabers community" melalui gaya hidup dan nilai-nilai realitas yang ditampilkan kelompok tersebut. Berdasarkan tujuan tersebut, paradigma yang digunakan dalam penelitian ini adalah paradigma kritis. Dimana secara ontologi, paradigma ini memiliki ciri realitas yang diamati (virtual reality) merupakan realitas semu yang telah terbentuk oleh proses sejarah dan kekuatan-kekuatan sosial, budaya, dan ekonomi-politik. Gaya hidup dan nilai-nilai realitas kelompok ini merupakan realitas semu yang terbentuk oleh kekuatan-kekuatan sosial (Kriyantono, 2010,53-54).

Dalam buku Qualitative Research Practice dikatakan bahwa penelitian kualitatif adalah pendekatan naturalistik, interpretatif, menyangkut pemahaman makna yang oleh manusia dilekatkan pada fenomena (tindakan, keputusan, kepercayaan, nilai, dan lainlain) dalam dunia sosial mereka (Ritchie dan Lewis, 2003). Berdasarkan pernyataan 
tersebut tipe penelitian ini tergolong penelitian kualitatif. Penelitian ini menyangkut interpretif makna yang ad pada sebuah fenomena.

Metode penelitian yang digunakan adalah metode analisis wacana. Analisis Wacana akan memungkinkan untuk memperlihatkan motivasi yang tersembunyi di belakang sebuah teks atau di belakang pilihan metode penelitian tertentu untuk menafsirkan teks. Topik utama yang menjadi pokok dalam analisis wacana adalah struktur sosial yang mendasarinya, yang dapat diasumsikan atau dimainkan dalam percakapan atau teks. Ini menyangkut alat dan strategi yang dipakai orang ketika terlibat dalam komunikasi. Dalam representasi dan stereotype dari gaya hidup "hijabers community" diharapkan bisa membongkar wacana dibalik gaya hidup anggotanya yang menjadi populer dikalangan masyarakat.

Teknik pengumpulan data yang digunakan adalah dokumentasi. Dokumentasi merupakan instrumen pengumpulan data yang sering digunakan dalam berbagai metode pengumpulan data. Tujuannya adalah mendapatkan informasi yang mendukung analisis dan interpretasi data (Kriyantono,2010;120).

\section{Sasaran Penelitian}

Objek penelitian merupakan masalah yang akan diteliti. Seperti pendapat Sugiono $(2009 ; 38)$, objek penelitian adalah suatu atribut atau nilai dari orang, objek atau kegiatan yang mempunyai variabel tertentu yang ditetapkan oleh peneliti untuk dipelajari dan kemudian ditarik kesimpulannya. Berdasarkan defenisi tersebut, yang menjadi objek penelitiannya adalah gaya hidup dari komuninas hijabers atau "hijabers community".

Subjek penelitiannya adalah salah satu teks yang diproduksi dari kelompok "hijabers community" yaitu iklan cetak dari beberapa kegiatan yang dilakukan dan diadakan oleh kelompok "hijabers community". Teksnya iklan tersebut adalah teks iklan cetak acara "Ngabuburit dan Silaturahmi HC (Hijabers Community) Jakarta" . Berikut adalah gambar iklannya:

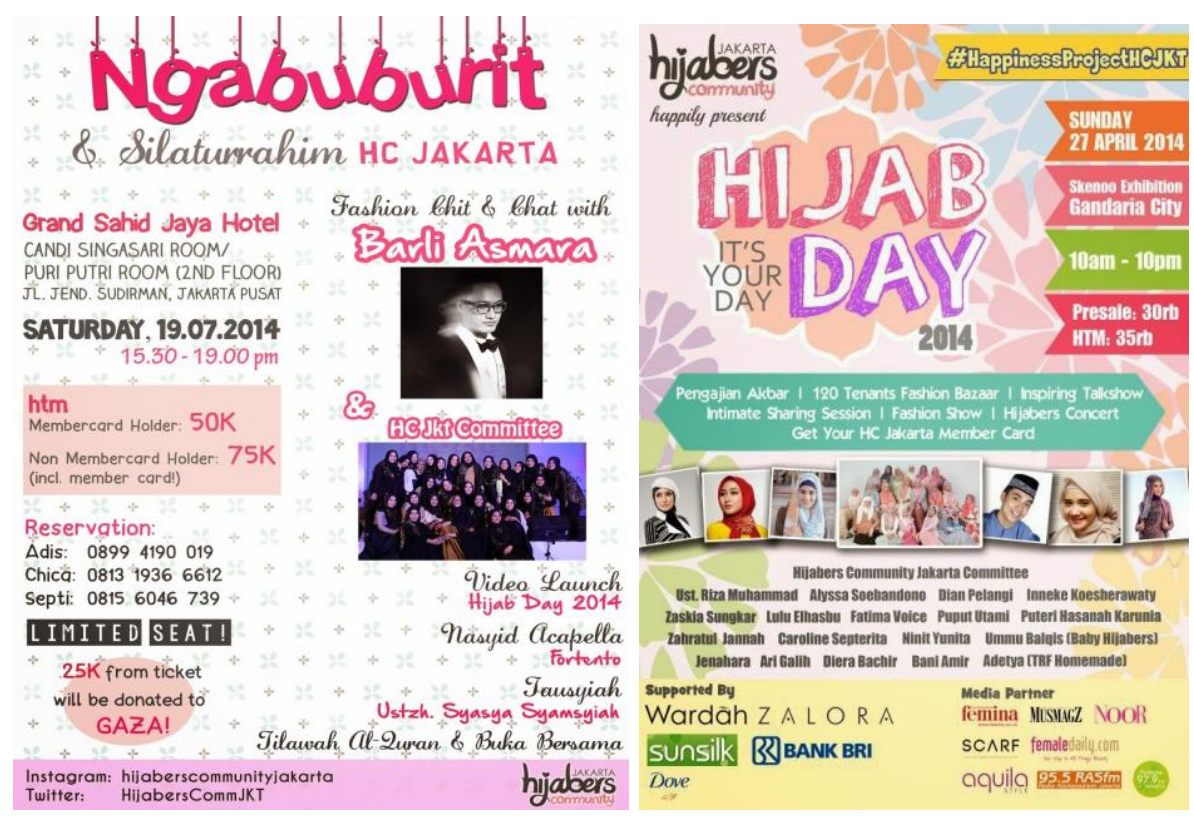

Sumber ; http://hijaberscommunityjakarta.blogspot.com/ 


\section{HASIL DAN PEMBAHASAN}

Hijabers Community didirikan pada 27 November 2010 di Jakarta. Anggotanya berjumlah 30 orang dari latar belakang profesidan kehidupan yang berbeda. Berkumpul bersama untuk berbagi visi mereka untuk membentuk sebuah komunitas yang akan mengakomodasi kegiatan yang terkait dengan jilbab dan muslimah. Anggota komunitas ini berusia dari 20-30 tahun dan berasal dari kelas masyarakat menengah. Komunitas ini dirintis oleh tiga wanita Muslimah yang memiliki persamaan visi dan misi dalam hal syiar agama dan fashion Islami. Ketiga wanita pendiri Hijabers Community adalah desainer busana Islami yang memiliki label busana masing-masing, yaitu Dian Pelangi dengan label busana DP by Dian Pelangi, Jenahara Nasution dengan label busana Jenahara, dan Ria Miranda dengan label busana Ria Miranda (http;//www.jenahara.com).

Selain itu, dalam tulisan salah satu perintis hijabers community, Jenahara dikatakan bahwa dari perjalanannya, hijabers community berhasil mengumpulkan anggota-anggota yang berjiwa muda, dinamis, energik, dan penuh kreativitas berkumpul dan berkegiatan yang sangat asyik dan positif, seperti workshop fashion, kelas kecantikan tata rias make up, program charity dan lain-lain dan yang pasti pengajian rutin. (http;//www.jenahara.com). Tulisan ini menjadi dasar bagi peneliti dalam menganalisis gaya hidup seperti apa yang dimiliki oleh anggota hijabers community. Pertama adalah sasaran dari kelompok ini. Berdasarkan kriteria tersebut sasaran utama dari kelompok ini adalah mahaasiswa dan eksekutif muda. Ciri-ciri anggota yang dikumpulkan adalah perempuan muda yang aktif dan kreatif, dinamis dan energik yang mudah diidentifikasikan pada mahasiswa dan eksekutuf muda.

Berikutnya adalah kegiatan yang diadakan berupa workshop fashion, kelas kecantikan tata rias make up, program charity dan lain-lain dan yang pasti pengajian rutin. Kegiatan-kegiatan tersebut merupakan kegiatan rutin yang diadakan kelompok ini. Kegiatan yang berbasis fashion, make -up dan kecantikan pada dasarnya adalah kebiasaan atau habitus dari golongan kelas menengah ke atas. Biasanya kegiatan ini menguras banyak uang. Kelas kecantikan biasanaya dilakukan oleh kalangan tertentu dan dengan tujuan tertentu yaitu orang-orang yang memang ingin mendirikan usaha dibidang kecantikan atau orang-orang yang inginmempelajari teknik-teknik tata rias. Dan biasanya dengan biaya yang mahal. Namun dengan adanya workshop fashion dan kelas kecantikan, dengan harga terjangkau dan diadakan dalam waktu sehari dan menginformasikan teknik-teknik dasar kecantikan, kegiatan ini jadi diminati banyak perempuan lainnya. Kegiatan lainnya yang biasa dilakukan oleh kalangan golongan menengah keatas yaiu kalangan yang mampu adalah program charity. Namun demikian kegiatan-kegiatan kelompok ini tetap mengandung syiar agama dan menyebarkan akhidah agama melalui acara pengajian yang rutin dilakukan minimal sekali dalam sebulan.

Diantara banyak kegiatan yang dilakukan, dua diatarang adalah "ngabuburit dan silaturahmi dengan HC Jakarta" dan acara "Hijab day 2014". Kedua kegiatan ini dilakukan di dua tempat mewah yaitu hotel dan mall. Dari lokasi yang dipilih bisa memperlihatkan bahwa lagi-lagi kegiatan ini ditujukan untuk perempuan menengah keatas tentunya yang berhijab. Untuk mengadakan acara di dua tempat tersebut pasti mengeluarkan budget yang mahal dan mendapatkan sponsor yang banyak. 
Rata-rata kegiatan yang dilakukan oleh kelompok ini, melibatkan artis-artis ataupun designer dan ahli fashion terkenal dengan bayaran juga fantastis. Seperti dalam dua acara tersebut, "ngabuburit dan silaturahmi dengan HC Jakarta" mendatangkan designer ternama Barlie Asmara, dimana rancangan-rancangannya dikonsumsi oleh perempuan kelas menengah keatas. Pada acara "Hijab day 2014" dihadiri artis-arti terkenal seperti Zaskia Sungkar, Alisha Soebandono, Dian Pelangi, Ineke Koesherawati, dan banyak lainnya, yang mana rata-rata mereka sudah memiliki butik dan brand busana sendiri.

Harga tiket masuk acara yang digelar oleh kelompok ini memang beragam, dari mulai yang free hingga mencapai ratusan ribu. Pada dua acara tersebut memang dengan harga yang cukup terjangkau. Pada acara "ngabuburit dan silaturahmi dengan HC Jakarta" dikenakan biaya 50.000 bagi anggota hijabers community dan 75.000 bagi non anggota. Begitu juga dengan acara"Hijab day 2014" dikenakan biaya 30.000 hingga 35.000. Meskipun dikenakan biaya yang terjangkau, tentunya acara - acar tersebut dibantu oleh sopnsor yang juga ingin mengambil keuntungan dari acara tersebut. Biasanya pada acara dilakukan bazar yang diikuti oleh para sponsor, seperti brand cosmetic Wardah, produk kecantikan lain seperti sampho, sabun dan laiinya majalah wanita, majalah muslimah dan produk-produk lainnya. Yang paling penting hijab dan busan-busan muslim dari butik dan brand yang dikeluarkan oleh artis-artis pengisi acara maupun anggota hijabers yang memiliki butik sendiri. Adanya bazar yang menampilkan barang-barang dari pihak sponsor mencirikan bahwa acara-acara tersebut mengajak pesertanya ikut berbelanja , dan pada akhirnya mengajarkan terbiasa menjadi konsumtif. Konsumtif yang merupakan gaya hidup kelas menengah keatas.

Berawal dari acara yang bertujuan dakwah seperti pengajian ataupun kelas kecantikan, kelompok ini menampilkan gaya hidup mereka yang dapat diidentifikasi dari lokasi acara, bintang tamu yang di undang, dan barang-barang yang di jual di bazar. Hargaharga yang menguras kantong dapat mengidentifikasikan siapa konsumen dari produkproduk mereka.

Kesan melekat mewah namun sederhana dan terjangkau mengelabui perempuan perempuan yang melihat kelompok ini dan terinspirasi mengikuti gaya hidup mereka. Tidak sedikit yang memaksakan membeli barang dengan harga yang setara di butik para desainer kelompok ini, mengikuti kelas-kelas kecantikan yang juga tidak lansung menguras uang. Muali dari membayar uang masuk, membeli produk-produk di bazar hingga menirukan trend fashion member dari kelompok tersebut, agar diakui setara dengan kelompok tersebut.

Berdasarkan analisis singkat tersebut dapat disimpulakan bahwa representasi dan stereotype gaya hidup yang melekat pada kelompok hijabers "hijabers community' tersebut adalah pola gaya hidup kelompok kelas menengah keatas yang lebih konsumtif, mengajarkan kita untuk konsumtif. Hal tersebut bisa diidentifikasi dari lokasi, bintang tamu dan sponsor acara-acara mereka. Representasi adalah produksi makna konsep dalam pikiran kita melalui bahasa.Bahasa yang digunakan dalam arti yang lebih luas merangkul setiap interaksi sosial dan ekspresi komunikasi dari kata-kata, suara dan gerak tubuh, halhal, pakaian atau warna, yang dikenal sebagai teks. Ada dua sistem representasi yang terlibat dalam produksi makna. Pertama terdiri dari konsep-konsep dunia yang terbentuk dalam pikiran kita yang diklasifikasi dalam kategori bermakna yaitu segala macam benda, orang dan peristiwa yang berhubungan dengan serangkaian konsep atau representasi mental 
yang kita bawa di kepala kita. Tidak hanya hal-hal yang dapat kita rasakan seperti orang atau benda material, seperti kursi, meja dan meja, tetapi kita juga konsep hal yang agak kabur dan abstrak, yang kita tidak bisa lihat, rasakan atau sentuh (Hall,1997;18-20).Dalam hal ini konsep-konsep yang ditampilkan oleh hijabers community dikategorikan pada kategori orang-orang kaya yang konsumtif, bergengsi, trendcenter dari gaya hidup, gaya berpakaian, hubungan pertemanan yang dibangun merupakan konsep-konsep dunia yang sudah terbentuk dikepala kita.

Sedangkan sistem representasi yang kedua adalah bahasa. Dengan bahasa kita berkomunikasi dan bertukar ide-ide ini. Kita juga harus mampu mewakili atau makna pertukaran dan konsep, dan kita hanya bisa melakukan itu ketika kami juga memiliki akses ke bahasa bersama. Oleh karena itu bahasa adalah sistem kedua representasi yang terlibat dalam keseluruhan proses membangun makna. Pemetaan konseptual tentang yang ada didunia ini harus diterjemahkan ke dalam bahasa yang sama, sehingga kita dapat menghubungkan konsep-konsep dan ide-ide kita dengan kata-kata tertulis tertentu, suara yang diucapkan atau gambar visual. Istilah umum yang kita gunakan kata-kata, suara atau gambar yang membawa makna tanda-tanda. Tanda-tanda ini berdiri untuk atau mewakili konsep dan hubungan konseptual yang kita bawa di kepala kita dan bersama-sama mereka membentuk sistem makna dari budaya kita. Bahasa diatur oleh kode bersama, aturan linguistik dan konvensi sosial sadar diinternalisasi oleh anggota budaya (Hall,1997;20). Tanda-tanda yang diproduksi hijabers community merepresentasikan hugh class.

Namun demikian, seperti yang diungkapkan Foucalt, dibalik wacana adanya kekuasaan. Pendekatan Foucault terhadap representasi berkaitan dengan produksi pengetahuan dan makna melalui wacana. Foucault juga menganalisis teks tertentu dan merepresentasi, seperti ahli semiotik lainnya lakukan. Tapi dia lebih cenderung untuk menganalisis pembentukan seluruh diskursif yang dimiliki teks atau praktek. Foucault dan pendekatan diskursif representasi menguraikan tiga ide utamanya: konsep wacana; isu kekuasaan dan pengetahuan. Perhatian-Nya adalah pengetahuan yang pada manusia dan ilmu-ilmu sosial, yang mengatur perilaku, pemahaman, praktek dan keyakinan, peraturan tubuh serta seluruh populasi. Karyanya sangat dipengaruhi 'berpaling ke bahasa' yang menandakan pendekatan representasi konstruksionis. Definisi tentang wacana yang jauh lebih luas daripada bahasa, dan mencakup banyak elemen lain dari praktek dan kelembagaan regulasi. Foucault selalu jauh lebih spesifik historis melihat bentuk kekuasaan / pengetahuan yang berakar dalam konteks tertentu dan sejarah. Di atas semua ini, untuk Foucault, produksi pengetahuan selalu disilangkan dengan pertanyaan kekuasaan dan tubuh; dan ini sangat memperluas ruang lingkup apa yang terlibat dalam representasi (Hall,1997;50)

Konsep kekuasaan Foucault berbeda dengan konsep kekuasaan yang telah ada sebelumnya. Foucault mendefinisikan kembali kekuasaan dengan menunjukkan ciricirinya, bahwa kekuasaan itu tersebar, tidak dapat dilokalisasi, merupakan tatanan disiplin dan dihubungkan dengan jaringan, memberi struktur kegiatan-kegiatan, tidak represif tetapi produktif, serta melekat pada kehendak untuk mengetahui. Kekuasaan Foucault bukanlah milik tetapi strategi. Kuasa ada dimana-mana, karena itu, kekuasaan bisa ditemukan dalam segala bidang interaksi manusia: keluarga, politik, ekonomi, sosial, agama dan sebagainya. Kekuasaan bagi Foucault tidak dipahami dalam suatu hubungan kepemilikan sebagai properti, perolehan, atau hak istimewa yang dapat digenggam oleh sekelompok kecil masyarakat dan yang dapat terancam punah. Kekuasaan juga tidak dipahami beroperasi secara negatif melalui tindakan represif, koersif, dan menekan dari suatu institusi pemilik kekuasaan, termasuk negara. 
Kekuasaan bukan merupakan fungsi dominasi dari suatu kelas yang didasarkan pada penguasaan atas ekonomi atau manipulasiideologi (Marx), juga bukan dimiliki berkat suatu kharisma (Weber) (Mudhoffir,2013;77). Kekuasaan tidak dipandang secara negatif, melainkan positif dan produktif. Kekuasaan bukan merupakan institusi atau stuktur, bukan kekuatan yang dimiliki, tetapi kekuasaan merupakan istilah yang digunakan untuk menyebut situasi strategis kompleks dalam masyarakat. Dalam hal ini Foucault tidak memisahkan antara pengetahuan dan kekuasaan. Tidak ada pengetahuan tanpa kekuasaan dan tidak ada kekuasaan tanpa pengetahuan. Tanpa kita sadari ajaran konsumtif yang ditanamkan pada perempuan berhijab tersebut, para perintis kelompok ini juga memiliki tujuan ekonomi, yaitu memperoleh keuntungan sebesar-besarnya melalui trend busana yang mereka populerkan, trend kecantikan yang mereka ajarkan, mereka jual melalui butik mereka.

Hasil representasi kelompok hijabers community tadi menimbulan stereotype baru dikepala perempuan. Menurut Devine (1989), beberapa stereotype kita unik dan didasari pada pengalaman individu masing-masing, tapi beberapa dibagikan dengan anggota yang lainnya dalam kelompok kita. Stereotype yang dibagikan tersebut dinamakan social stereotype. Social stereotype ini juga sering digunakan dalam media, untuk itu kita banyak belajar stereotype dari media. Kita terkadang memang mengetahui tentang stereotype suatu kelompok, namun kita tetap berpegang pada pandangan lain terhadap kelompok tersebut (Gudykunst, 2003;128). Ada beberapa stereorype yang ingin dibangun oleh kelompok ini, yaitu dimana hijab yang dulu indentik atau memiliki stereotype ketinggalan jaman. Menjadikan perempuan terbatas dalam mode dipatahkan melalui hasil representasi yang ingin mereka bangun. Melalui kegitan-kegiatan dan promo-promonya menjadikan stereotype perempuan berhijab adalah hal yang tidak umum, tertutup, terbelakang ketinggalan jaman, menjadi wanita yang bias jadi pusat perhatian trend center, cerdas, bergengsi. Jilbab tidak lagi sekedar pakaian penutup kepala tetapi menjadi tempat memperlihatkan status dan prestise. Untuk mencapai pengakuan sosial yang tinggi, sehingga tidak jarang perempuan menganut budaya konsumerisme.

Streotype baru yang digiring oleh hijabers community terhadap perempuan berhijab berusaha ditularkan kepada perempuan-perumpuan lainnya di Indonesia. Bahwa perempuan berhijab dimanapun akan terlihat keren dan berkelas dengan bergabung dihijab comunity. Sehingga banyak perempuan yang ingin bergabung dengan harapan mereka akan lebih eksist. Hal tersebut menjadi populer dikalangan perempuan Indonesia. Budaya populer yang merupakan budaya rakyat, yang dikonsumsi oleh masyarakat banyak, direpresentasikan dengan banyak sudut padang tentunya. Budaya populer biasanya digunakan untuk mendapatkan informasi sebanyak-banyaknya, salah satunya informasi tentang suatu kebudayaan. Bahwa Hijabers community ini mengidentifikasi kan perempuan dengan trend center, terdepan dan berkelas.

\section{PENUTUP}

Berdasarkan analisis singkat tersebut dapat disimpulakan bahwa representasi dan stereotype gaya hidup yang melekat pada kelompok hijabers "hijabers community" tersebut adalah pola gaya hidup kelompok kelas menengah keatas yang lebih konsumtif, mengajarkan kita untuk konsumtif. Tanpa kita sadari ajaran konsumtif yang ditanamkan pada perempuan berhijab tersebut, para perintis kelompok ini juga memiliki tujuan 
ekonomi, yaitu memperoleh keuntungan sebesar-besarnya melalui trend busana yang mereka populerkan, trend kecantikan yang mereka ajarkan, mereka jual melalui butik mereka. Ada beberapa stereorype yang ingin dibangun oleh kelompok ini, yaitu dimana hijab yang dulu indentik atau memiliki stereotype ketinggalan jaman. Menjadikan perempuan terbatas dalam mode dipatahkan melalui hasil representasi yang ingin mereka bangun. Melalui kegitan-kegiatan dan promo-promonya menjadikan stereotype perempuan berhijab adalah hal yang tidak umum, tertutup, terbelakang ketinggalan jaman, menjadi wanita yang bias jadi pusat perhatian trend center, cerdas, bergengsi. Jilbab tidak lagi sekedar pakaian penutup kepala tetapi menjadi tempat memperlihatkan status dan prestise. Untuk mencapai pengakuan sosial yang tinggi, sehingga tidak jarang perempuan menganut budaya konsumerisme. Budaya populer yang merupakan budaya rakyat, yang dikonsumsi oleh masyarakat banyak, direpresentasikan dengan banyak sudut padang tentunya. Budaya populer biasanya digunakan untuk mendapatkan informasi sebanyak-banyaknya, salah satunya informasi tentang daerah ataupun kebudayaan dari daerah lain yang belum pernah dikunjung yang pastinya memiliki kebudayaan yang berbeda. Faktanya, budaya sendiri adalah sebuah sistem representasikan oleh hijabers community.

\section{DAFTAR PUSTAKA}

Barker, Chris. 2000. "Cultural Studies”. London; Sage

Fiske, Jhon, 2004. ".Cultural and Communication Studies : Sebuah Pengantar Paling Komprehensif”. (terjemahan Idy Subandy Ibrahim) Yogyakarta: Jalasutra, 2007

Gudykunst, Willian B. dan Kim, Young Yun. 2003. Communicating With Stranger: An Approach to Intercultural Communication, Fourth Edition. Boston: McGraw Hill.

Hall, Stuart. (1992) 'The West and the Rest', in Hall, S. and Gieben, B'. (eds), Formations of Modernity,Cambridge, Polity Press;The Open University.

Hall, Stuart. 1997. "The work of representation". In Representation: Cultural Representations and signifying practices, edited by Stuart Hall, London: Sage.

Ibragim, Idi Subandi. 2007. "Budaya Populer sebagai Komunikasi”. Yogyakarta; Jalasutra

Kriyantono, Rahmat, . 2010 . Teknik Praktis Riset Komunikasi. Jakarta : Kencana PrenadaMedia Group.

Nakayama, Thomas K, and Martin, Judith N., 2007. Intercultural Communication in Contexts, Fourth Edition. New York: McGraw Hill.

Ritchie, Jane and Jane Lewis. 2003. "Qualitative Research Practice : A Guide for Social

Science Students and Researchers". London : Sage Publications

Sugyono, 2011. Metode Penelitian Kuantitatif Kualitatif dan R\&D. Bandung; Alfabeta Jurnal

Hübinette, Tobias. 2004 "Representations of East Asians in contemporary Swedish popular culture - intersections of race, gender and sexuality"

Mudhoffir, Abdil Mughis, 2013. "Teori Kekuasaan Michel Foucault: Tantangan bagi Sosiologi Politik” Univesitas Negri Jakarta; Jakarta

Deng, Dongyuan, 2009. "Stereotypes Communication. Yunnan Normal University of Business School ;Kunming

Shuli Zhang (Corresponding author) 